\title{
NOTES
}

\section{CHARACTERIZATION OF SURVIVAL OF TORT ACTIONS}

$\mathrm{T}$

He traditional approach in conflict of laws cases has been to characterize the particular problem as substantive or procedural and in that manner to determine which law should govern the case. ${ }^{1}$ The oftrepeated formula is that matters of procedure are governed by the law of the forum ${ }^{2}$ and that matters of substance are governed by the law of the locus. ${ }^{3}$ There is probably no concept in the law which has been more misleading than the supposedly obvious and inexorable distinction between substance and procedure. ${ }^{*}$ The prevailing and minority opinions of the Supreme Court of California in the recent case of Grant v. McAuliffe are illustrative. ${ }^{5}$

Suit was brought in a California court against the administrator of the estate of a California decedent for personal injuries sustained in an automobile accident which had occurred in Arizona. According to

\footnotetext{
${ }^{1}$ See generally Robertson, Characterization in the Conflict of LaWs (I940); Lorenzen, The Qualification, Classification, or Characterization Problem in Conflict of Lawe, 50 YALE L.J. 743 (194I); Cormack, Renvoi, Characterization, Localization and Preliminary Questions in the Conflict of Laws, I4 So. CaLIF. L. REv. 221 (194I); Falconbridge, Characterization in the Conflict of Laws, 53 L.Q. REv. 235 (1937).

2 The development of the rule that as to matters of procedure the law of the forum governs is based on necessity and practicality. A limitation on the scope of reference to foreign law is necessary since it is the judicial machinery of the forum that enforces the foreign law. The fact that foreign procedure may be difficult to apply or would inconvenience and burden the courts of the forum is a reality. See GooDRICH, CoNflict of LaWs $\S 80$ ( $3 \mathrm{~d}$ ed. 1948); Restatement, Conflict of LaWs, Introduction, c. I2 (1934); II AM. JUR., Conflict of Laws $\$$ I86, at 499 (I937); I5 C.J.S., Conflict of Laws $\$ 22$, at 948 (1939).

3 Beale, Conflict of Laws $\$ 584 . \mathrm{x}$, at I600; i I AM. JUR., Conflict of Laws $\S \mathrm{I} 4$, at $3 \mathrm{I}_{4}$ ( 1935$)$.

"In Cook, The Logical and Legal Bases of the Conflict of Laws i6o, i87 (1942) the writer sets out and criticizes decisions wherein the assumption that a particular word has an invariable meaning was expressed. See also ROBERTson, op. cit. supra note $\mathrm{I}$, at 157-223; ChamberLayne, THE Modern LAW of Evidence $\S$ I7I (x9II), who reasons that "substance" and "procedure" are purely illusory; In Cook, "Substance" and "Procedure" in the Conflict of Laws, 42 YALE L.J. 333, 344 (1933), the author formulates the following test for determining whether a problem is substantive or procedural: "How far can the court go in applying the rules taken from the foreign system of law without unduly hindering or inconveniencing itself?"; see Cheatham, Internal Law Distinctions in the Conflict of Laws, 2 I CORNELL L.Q. 570, 579 ( 1936$)$, wherein the author sets forth a somewhat similar convenience test.

5264 P.2d 944 (Cal. I953).
} 
the common law of Arizona, a cause of action for personal injuries does not survive the death of the tortfeasor ${ }^{6}$ California, however, by statute, had abrogated the common law rule. ${ }^{7}$ The District Court of Appeals affirmed the trial court's application of Arizona law to sustain the defendant's plea in abatement ${ }^{8}$ but the Supreme Court of California reversed the decision, four to three. The majority ruled that the survival of a tort action was a procedural question for the conflict of laws purpose and applied the law of the forum. ${ }^{\circ}$ The court distinguished a recent decision in which, in a slightly different setting, it was held that the question of survival was one of substance. ${ }^{10}$ Said Mr. Justice Traynor:

"S 'Substance' and 'procedure' ... are not legal concepts of invariable content." Black Diamond Steamship Corp. v. Robert Stewart \& Sons, 336 U.S. 386 [1949] . . . and a statute or other rule of law will be characterized according to the nature of the problem for which a characterization must be made. ${ }^{11}$

'ARIz. C.A. $\$ \$ 21-534$ (1939). For the general common law rule as to the survival of a cause of action for personal injuries, see GoODRICH, op. cit. sufra note 2, $\S$ ror, at 294; I C.J.S., Abatement and Revival $\S 143$, at r96 (1936).

${ }^{7}$ Cal. Civ. Code $\$ 956$; Cal. Code Civ. Proc. $\$ 385$, Cal. Prob. Code $\$ 573$ (1949).

${ }_{225}^{82}$ P.2d 819 (Cal. App. 1953). 'See note 2 supra.

${ }^{10}$ Cort. v. Steen, 36 Cal.2d 437, 224 P.2d 723 (1950). This was an action for property and personal injuries against the administrator of the deceased tortfeasor. The tort had occurred before the enactment of a California statute abrogating the common law rule abating actions for personal injuries upon the decease of the tortfcasor. All the contacts of the case were within California. In a four to three decision, the California Supreme Court held that the survival statute was substantive, and therefore could not be retroactively applied.

${ }^{11}$ Compare the various results of the characterization in the following cases: Black Diamond Steamship Corp. v. Robert Stewart \& Sons, 336 U.S. 386 (1949), wherein the issue of measure of damages resulting from a collision in Belgian territorial waters involving a United States owned vessel was considered procedural; Guaranty Trust Co. v. York, 326 U.S. 99 (1945), wherein the New York statute of limitations barring action was characterized as substantive and binding on the federal court in that state, thereby disallowing derivative action against a trustec for breach of fiduciary duties; Sampson v. Channell, r ro F.2d 754 (rst Cir. 1940), whercin in an action for personal injuries sustained in an automobile collision in Maine, the federal court in Massachusetts held that the burden of proving contributory negligence was determined by a substantive rule and hence that the conflict of laws rule of Massachusetts applied. See also Cook, op. cit. supra note 4. In Cook, "Substance" and "Pro. cedure" in the Conflict of Laws, 42 YALE L.J. 333, 337 (1933), the author states, "The tendency to assume that a word which appears in two or more legal rules, and so in connection with more than one purpose, has and should have precisely the same scope in all of them, runs through all legal discussion. It has all the tenacity of original sin and must constantly be guarded against." Briefly, this statement typifies the view of those who believe that no arbitrary rule of characterization is workable. Examples 
The dissenters decried the rule set up by the majority as leaving future decisions to the "untrammeled whimsy" of the court, and mourned the passing of a "government of laws rather than of men."12

Although one might share the misgivings of the minority as to the rationale of the majority, the outcome of the case seems eminently "correct." The plaintiffs and decedent were citizens of California; the estate of the deceased was being administered there; indeed, the only contact with Arizona was the happenstance that the accident out of which the litigation arose occurred there. Instinctively, this is one of those situations in which the court of the forum ought to apply its internal law if a legitimate rationale is available.

Characterizing the question of survival of tort liability as "procedural" was not, however, a satisfactory rationale for this decision. Whatever may have been the original basis for the notion that survival goes only to the remedy rather than to the substance of a case, the idea can no longer be considered acceptable. ${ }^{13}$ Whether a plaintiff will be allowed to recover is not a remedial or procedural matter; it is a

of characterization according to the nature of the problem involved are Tucker $v$. Alexandroff, $\mathrm{I}_{3}$ U.S. 424 (1902), wherein a launched craft, still incomplete, was held to be a "vessel" in order to give admirality jurisdiction over deserting seamen; Seabrook v. Raft of Railroad Cross Ties, 4o Fed. 596 (D.S.C. 1889), wherein a raft of logs was held to be a "vessel" for the purpose of giving a maritime lien for damages resulting from a collision.

${ }^{12} 264$ P.2d 944, 950 (Cal. 1953). The dissenters here were also in the minority in Cort v. Steen, 36 Cal.2d 437, 440, 224 P.2d 723, 726 (x950). See note ro supra. It would seem that even through they disagreed with the characterization of survival of a cause of action for personal injury as substantive in the Cort case, they have subordinated their convictions in order to promote consistency in the characterization of survivability. For a criticism of the minority's hope for consistency, see LORENZEN, Selected ARticles on the Conflict of LaWs it (1947).

${ }^{13}$ The majority in the Grant case noted that formerly it had been held that the question of survival of a tort claim was procedural. 264 P.2d 944, 947 (Cal. 1953). However, after the circulation of the Restatement, Conflict of Laws in 1929, the majority of decisions have characterized the survival of tort claims as substantive. Hence the law of the place of injury must govern. Undoubtedly, the argument for uniformity of decision, regardless of the place of the forum, caused reversal of the prior view. That the law of the place of injury governs survival see 2 BEALE, $o p$. cit. supra note $3, \S 390.1$; GoODRICH, op. cit. supra note $2, \S 92$, at 260 ; RESTATEMENT, CONFLICT of LAws $\$ 390$ (r934); ix AM. JUR., Conflict of Laws $\S 78$, at 68 (1936); and cases cited by the majority in the Grant case, 264 P. 2d 944, 946-947 (Cal. 1953), holding that the survival of a cause of action for personal injuries is a substantive matter governed by the law of the place where the injury occurred. For a criticism of the "place of injury" standard see Stumberg, Conflict of LAws $20 \mathrm{r}$ (2d ed. 195I); See also Comment, Functional Application of Conflict of Laws Rules in Tort Cases, 44 YALE L.J. 1233 (1935), suggesting that consideration of the social purposes behind particular rules of law might serve to bring about more satisfactory results than would "Glind" application of the "place of tore" standard. 
matter of the existence or nonexistence of a right. ${ }^{14}$ And even though one does not share the opinion of the minority that the terms "substance" and "procedure" should have an invariable and definite content, it is obvious that the manipulation of the terms in which the court indulged in the present case may lead to embarrassment in future litigation. Suppose, for example, that two Arizona residents collide in Arizona, one being injured as a result of the negligence of the other. Suppose, then, that the tortfeasor dies and for some reason the suit is brought against his administrator in California instead of Arizona. In such a fact situation, the only contact which California would have with the case would be that it was the state of the forum, and it is improbable that the California court would wish to apply its own law in preference to that of Arizona. Yet, under the present holding it could not do otherwise. No matter how manipulable the majority considers the concepts of procedure and substance, the principle of stare decisis would not permit characterizing the question as substantive without flatly overruling the present case.

It is a well settled rule of conflict of laws that in a single-state tort action the law of the locus delicti governs as to the existence, nature, and extent of a right. ${ }^{15}$ No matter how the foreign forum gives effect to this right, whether it be according to "comity, "10 the "vested rights"

${ }^{14}$ See Gray v. Gray, 87 N.H. 82, 174 Atl. 508 (1934), holding that the right to sue is substantive; Dawson v. Dawson, 224 Ala. 13, 138 So. 414 (1931).

${ }^{15}$ Apparently, and reasonably, in many cases the law of the place of the wrong is applied because it is the only controlling law where the injury occurred. Sce GoopRICH, op. cit. supra note $2, \S 92$, p. $26 \mathrm{I}$. In addition, precedent, treatics, and the full faith and credit clause, U.S. CONST. ART. IV, $\S \mathrm{I}$, have been advanced as arguments for the application of the law of the place of the wrong. See Chentham, American Theories of Conflict of Laws, Their Role and Utility, 58 HARv. L. REv. 361 (1945). See also LORENZEN, CASES ON CONFLICT OF LAWS 362 (4th ed. 1937); RESTATEMENT, CONFLICT OF LAWS $\$$ 377-379 (1934).

Where the acts leading up to the tort are not confined to one state, a problem arises as to what law is to govern. Thus, in the case of a multiple state tort problem, application of the "place of wrong" standard may not be practical. For recognition of the difficulties in a multiple state tort situation, see REsTatement, Conflict of Laws $\S 382$ and comments (1934); Rheinstein, Place of Wrong, 19 TULANE L. REv. 4 (1931).

${ }^{16}$ The "comity" doctrine, as used in the United States, is attributed to Mr. Chief Justice Story. See STORY, CONFLict of LAws (8th ed. 1883 ). This doctrine is to the effect that the law of the sovereign is territorial and without legal effect beyond its boundaries. However, when a foreign-created right is to be enforced, the forum, recognizing the necessity for having its own rights enforced in a foreign forum when the occasion requires, will apply the foreign law to the particular adjudication. For an example of Story's approach, see Hilton v. Guyot, 159 U.S. I13 (1895), wherc the United States Supreme Court held that the merits of a French judgment, sought to be enforced in a United States court, may be re-examined, since a French court would reappraise the merits of an American judgment sought to be enforced in a French court. 
theory ${ }^{17}$ or the "local law" theory ${ }^{18}$ selected by the majority in this case, the result should be the same. Thus, initially, the present decision seems to be unsupportable on any theory.

However, the question here is not of the existence, nature, or extent of the right, but of the effect of an event which occurred after the commission of the tort, namely the death of the tortfeasor. ${ }^{19}$ Conceding that, absent this fact, the parties should have been governed by the substantive law of Arizona, it does not follow that California has to apply the law of Arizona in order to determine the effect of this subsequent event on the original cause of action. Suppose that before the tortfeasor died he had executed a release in California. It would seem that the California court would not be obliged to apply the substantive law of Arizona to determine the effect of this release even though the

${ }^{17}$ The "vested rights" theory is attributed to Professor Beale, who thought it inconceivable that a foreign law could operate in the forum. See I BEALE, op. cit. supra note $3, \S 8 \mathrm{~A} .7$, at 63 . An illustration of the "vested rights" theory is Slater v. Mexican Nat. R., I 94 U.S. I02, 126 (1904), where Mr. Justice Holmes stated: "The theory of the foreign suit is that although the act complained of was subject to no law having force in the forum, it gave rise to an obligation, an obligation, which like other obligations, follows the person, and may be enforced wherever the person may be found."

"The "local law" theory is a repudiation of the "comity" theory and the "vested rights" theory. In practice, the right which the forum enforces is one created by the law of the forum, though modeled on the right existing under the law of the place of occurrence. An example of the "local law" theory in practice is Guinness v. Hicks, 291 Fed. 769 (S.D.N.Y. 1923), modified, 269 U.S. 7 I (1925). (This was a suit to recover a debt owed by a German citizen where payment was to be made in German marks, and the issue was whether the value of the marks in dollars as of the date when the debt matured or the value at the date of the decree was to govern the amount of recovery. Held, following the "local law" theory, that the value of marks in dollars as of the date when the stated account became payable measured the amount of recovery.) Walter Wheeler Cook and Judge Learned Hand are considered as being responsible for the "local law" theory. Cavers, The "Local Law" Theories, 63 HARv. L. REv. 823 (1950), wherein it is suggested that there are two "local law" theories. Hand's theory would first require that a right be created by the law of the locus, after which the forum is to "model" its right. "It is a matter of no concern (to Cook) whether the foreign state has created a right in the plaintiff under its law. When the forum finds it appropriate to look to the law of another state it seeks simply a rule of decision to use in disposing of the case." Id. at 824-825. For a criticism of the "local law" theory, see de Sloovere, The Local Law Theory and Its Implications in the Conflict of Laws, 4I HARv. L. REv. 42I (1928). For an analysis of all three theories, see Cheatham, note 4 supra: Dodd, The Powers of the Supreme Court to Review State Decisions in the Field of Conflict of Larus, 39 Harv. L. REv. $533(1926)$.

10 "Under that standard [place of wrong] the effect of death of one of the parties upon the cause of action is, as has been indicated, determined by reference to the law of the place of injury, although the fact of death and the question of survivorship have nothing to do with either the injury or the conduct of the defendant." STumberG, op. cit. s:tare nete $\mathrm{I}_{3}$, it 205 . 
tort occurred in Arizona. ${ }^{20}$ The same reasoning is appropriate here. It does not appear from the opinion where the tortfeasor died; yet, even assuming that he died in Arizona, this would be the single contact which would authorize resort to Arizona law to determine the effect of his death on this cause of action. On the other hand, the tortfeasor was domiciled in California ${ }^{21}$ his estate was being administered there under California law; and the responsibilities of the defendant, as administrator, were governed by the laws of California. Logic and reason should permit the California court to apply its own law in deciding the effect of the death of one of its citizens when, as here, the material contacts associated with this event are with California.22

It would seem, in conclusion, that if the California court in the instant case had viewed the death of the tortfeasor as an event separate and apart from the acts giving rise to the cause of action in Arizona, it might well have applied the substantive law of California in determining the effect of that subsequent event. In this manner, the court would have been able to reach the same decision without the unnecessary abuse of the distinction between substance and procedure.

\section{Paul Hardin III \\ WILLIAM KaELIN}

\footnotetext{
${ }^{20}$ STUMBerg, op. cit. supra note 13 , at 206 , points out that "The common law rule is that a cause of action for personal injury does not survive the death of the plaintiff or defendant. Consequently, the cause of action, in states where the rule is in force, is neither an asset of the estate of the injured party nor a liability of the estate of the tortfeasor. Where statutory changes have been made, the effect has been to make the cause of action an asset or a liability. Apparently, then, survivorship of actions is more clearly akin to administration of estate than to tortious injurics. It would seem therefore that since administration is generally determined by the decedent's domiciliary law, that law might also be controlling here, with the effect of the death of the plaintiff or of the defendant determined by the law of their respective domicils." As to which law will govern a release, see 2 BEALE, op. cit. supra note 3, at 1275 ; Restatement, Conflict of Laws $\$ \$ 332,355,374$ (1934).

${ }^{21}$ The significant role played by domicile in conflict of laws decisions is discussed in GoODRICH, op. sit. supra note 2, c. 2; see also HOLLAND, JURISPRUDENCE 409, 412 (1 $3_{\text {th }}$ ed. 1924), listing domicile as one of the contact factors which may be resorted to in determining which law is to govern in a conflict of laws case.

In Whitten v. Bennett, 77 Fed. 27 (C.C.D. Conn. 1896 ), in an action against the administrator of the deceased tortfeasor for false imprisonment, the forum determined survival by the law of the decedent's domicile rather than by the law of the place where the tort occurred.

${ }^{22}$ A recent illustration of the "contacts" approach in solving choice of law problems in Barber v. Hughes, 223 Ind. 570, 586, 63 N.E.2d 417, 423 (1945). This was a suit to enforce a cognovit contained in a promissory note. Indiana, by statute, had invalidated such confession of judgment provisions. In determining whether Indiana or Illinois was to be considered the "place of making," the Indiana Supreme Court said: "The court will consider all acts if the parties touching the transaction in relation to the several states involved and will apply as the law governing the transaction the law of that state with which the facts are in most intimate contact."
} 